\title{
Święty Tomasz, Wielki Gatsby i poszukiwanie szczęścia
}

Anna Białas (Poznań)

\section{Eudajmonia czyli ponadczasowa dążność do szczęścia}

Kohelet wieścił, że życie ludzkie to wyłącznie marność, gonitwa za wiatrem i ułuda. Czy w świecie pełnym trosk przyziemnych, acz dojmujących człowiek ma szansę na odrobinę zadowolenia? Czy można być szczęśliwym tak po prostu, bez żadnych warunków? Nim odpowiemy na to pytanie, warto przyjrzeć się filozoficznym definicjom szczęścia. Obserwacje pokazują że szczęście jest dobrem najbardziej poszukiwanym i pożądanym, a jednocześnie - najmniej dostępnym poznaniu. Być może jest ulotnym błogostanem, do którego człowiek dążył zawsze i nigdy dążyć nie przestanie? Być może klucz w utrwaleniu tego, co przygodnie nas raduje i zadowala? Jak można je sprecyzować, czy definicja ma w sobie treść uniwersalna, czy może tylko subiektywną? Gdy wejrzymy w słownikowe wykładnie, przekonamy się, że szczęście to stan odczuwania pozytywnych emocji, takich jak przyjemność czy zadowolenie. Odczuwanie zaś jest czymś wewnętrznym, indywidualnym: zatem treść słowa „szczęście” wydaje się definiowalna dla każdego człowieka na nowo, w zależności od jego osobistych dążeń, aspiracji, nadziei, oczekiwań. Dla uczonego szczęściem może się okazać sensacyjne odkrycie naukowe, dla filozofa - sformułowanie ostatecznej teorii dla zagadnień, które zaprzątają ludzkość od zarania, odkąd poczęła się interesować sobą otaczającym światem i współtworzonym z innymi społeczeństwem: odkąd sama generować zaczęła problemy, pytania i dylematy. Osobom religijnym szczęście może wydać się nieskończenie odległe, jeśli oznacza Zbawienie: tutaj, podczas ich ziemskiej egzystencji prawdziwe szczęście uświadczyć trudno. Znowuż zjadaczom chleba o 
innej misji aniżeli vita contemplativa pełnię szczęścia zapewnią zdrowie, majątek, przystojny partner życiowy lub kariera, rozumiana tak czy inaczej.

W każdej księgarni natrafimy na dział Poradników. Większość pomieszczonych tak tomów traktuje szeroko i optymistycznie o tym, którędy ku szczęściu (zwykle jest to droga na skróty). Autorzy tych prac posługują się terminem „szczęście" w rozległym, ogólnikowym, intuicyjnym sensie bliżej nieokreślonego błogostanu. Inni wierza, że odkryli definicję ostrą i konkretną bo bardziej uchwytną dla zwykłego śmiertelnika: jako spełnienie zawodowe, osiągnięcie wymarzonej figury, odkrycie talentu czy też pasowanie na idealnego kochanka, idealną kochankę. Czyż nie jest to jednoznaczny dowód na to, że pragnienie szczęścia tkwi w ludzkiej duszy człowieku niezależnie od czasu i miejsca, w jakich przyszło mu żyć. Tu jednak rodzi się pewien niepokój: czy człowiek dąży do szczęścia (przykrojonego do indywidualnych definicji) czy też stawia sobie coraz to nowe cele do realizacji, będąc święcie przekonanym, że po przejściu wszystkich siedmiu bram, siedmiu gór i rzek czeka go zasłużony błogostan, ziemia obiecana ludzkiego szczęścia? Czy nie jest raczej tak, że musimy przedsiębrać kolejne cele, podejmować kolejne działania, budować strategie i etapy pośrednie, i że droga do szczęście niemiłosiernie się rozciąga i wydłuża, a nasza wędrówka i znój pozbawiają nas z wolna ułudy, że gdzieś tam u kresu czeka nas zasłużona nagroda, idylla, o której wiemy tyle, ile włoży w nią projektująca siła naszych marzeń?

W polskim społeczeństwie, zgorzkniałym i niechętnym zwykle uśmiechowi, szerzy się ostatnimi czasy swoista moda na atrakcyjność, sukces i nieodłączne od nich samozadowolenie - autentyczne albo przynajmniej inscenizowane przez innymi. Można mówić nawet o istnieniu tzw. stresu związanego ze szczęściem, czyli stanu, kiedy to szczęście jest czymś obowiązkowym, oczywistym i rzeczywistym, a nie - jak do tej pory - jedną z możliwości, jaką osiąga ludzka kondycja. Z pewnością stres pogłębiony jest brakiem fachowej wiedzy o tym, czym właściwie jest szczęście: no bo jak zmierzać do czegoś, czego się nie zna? Moda ta napotyka na podaż wspomnianych poradników. Czy ten alians wróży powodzenie?

\section{Sokrates, Platon, Arystoteles: filozofia odkrywa szczęście}

Niemal od samego początku swojego istnienia filozofowie rozglądali się za odpowiedzią na pytanie, czym jest szczęście, jak je osiągnąć i zatrzymać na dłużej, być może na całą wieczność. Niejednokrotnie usiłowany stworzyć taki system etyczny, który czyniłby ze szczęścia postulat (eudajmonia), a z dróg do szczęścia życiowe środki i strategie pomocne ludziom przemyślnym, a czasem i bezmyślnym (medytacja). Więc cóż takiego uznawali filozofowie za godne miana „szczęścia”? Dla 
Sokratesa szczęście wiązać się miało z najwyższą cnotą czyli poznaniem dobro i umiejętność posługiwania się tą samą cnotą w działaniu. Podobnie uważał jego uczeń Platon. Kolejny wielki myśliciel Starożytności, Arystoteles, upatrywał szczęście w praktycznym ludzkim dążeniu do wewnętrznej doskonałości moralnej, do mądrości i sprawiedliwości jako trwałej jakości ludzkiej natury. Pojawiły się też koncepcje wymagające od człowieka mniej zachodu, takie jak hedonizm głoszący, że szczęścia najlepiej szukać $\mathrm{w}$ doczesnych uciechach i przyjemnościach, w zaspokojeniu indywidualnym, a czasem także wzajemnym bądź zbiorowym. Filozofia Antyku rozważając szczęście celowała w człowieka jako indywiduum, w jego potrzeby, możliwości i wysyłki na rzecz zaspokojenia potrzeb. Szczęście miało tu być zasługą i dziełem tego, kto sobie na nie zapracował. Dla odmiany, badacze tej subtelnej materii odkryli w czasach średniowiecza inne źródła szczęścia: niezasłużona, transcendentą łaskę. Część z nich podjęła jednak antyczny motyw zasługi ; tyle że realizację szczęścia odraczać zaczęto i odwlekać w sferę innego, nadprzyrodzonego życia. W taki oto sposób szczęście doczekało się sakralizacji.

\title{
3. Tomasz z Akwinu o szczęściu
}

\begin{abstract}
Szczęście można ujmować dwojako. Po pierwsze, ze względu na jego istotę ogólną. I wówczas jest rzeczą konieczna, aby każdy człowiek chciał szczęścia (...). Stąd pragnienie szczęścia nie jest niczym innym jak pragnieniem zaspokojenia woli, a tego chce każdy. W inny jednak sposób możemy mówić o szczęściu, biorąc pod uwagę jego istotę szczególna, czyli to, na czym ono polega. I wówczas nie wszyscy rozpoznają szczęście, gdyż [niektórzy] nie wiedza, jakiej rzeczy przysługuje ogólna istota szczęścia. I w tym sensie nie wszyscy go chcą. (TS, s. 116)
\end{abstract}

Powyższe słowa pochodzą z Traktatu o szczęściu, fragmentu Summy teologicznej św. Tomasza z Akwinu. Podejmuje on w Traktacie kwestię zasadniczą: ostateczny cel człowieka w jego kondycji, trwaniu i przeznaczeniu. Cel ten uznaje za najwyższe dobro, utożsamiając je ze szczęściem. Inspiracją dla Akwinaty, zarówno w budowie dzieła, jak i w sposobie ujęcia tytułowego zagadnienia była Etyka Nikomachejska Arystotelesa. Ponadto, Tomasz siłą rzeczy tematyzował szczęście w kontekście dogmatyki chrześcijańskiej. Skoro wybitny teolog i filozof zajął się szczęściem w swoim opus magnum, łatwo wywnioskować, jak doniosła była to problematyka dla ówczesnych intelektualistów.

Traktat o szczęściu dzieli się na pięć kwestii, a każda podzielona jest dalej na osiem artykułów. Dane zagadnienie rozważane jest tutaj ze wszystkich stron, we wszystkich aspektach. Analizowane są odpowiedzi za i przeciw (zgodnie ze schematem stosowanym w scholastyce). Całe dzieło jest czymś pośrednim pomiędzy traktatem a serią dyskutowanych zagadnień. Kwestie podejmowane przez Akwinatę 
obejmują ostateczny cel człowieka, przedmiot ludzkiego szczęścia (w czym je człowiek lokuje), materię szczęścia, warunki szczęścia i osiąganie szczęścia. Rozważa on również dość kontrowersyjną tezę, jak na swoje czasy: czy istnieją osoby, które mogą być bardziej szczęśliwe od innych?

Rozmyślania na temat szczęścia Tomasz z Akwinu rozpoczyna od próby ustalenia, co dla ludzi jest celem najważniejszym i ostatecznym. W jego przekonaniu w życiu każdego człowieka pojawiają się rozmaite cele, stawiane według określonej hierarchii (indywidualnej dla każdego). Człowiek jest w stanie zrealizować swoje zamierzenia dzięki aktywności intelektu i woli. Cel rodzi się w intelekcie, natomiast dążenie do jego realizacji zależy od woli, która jest siłą ukierunkowującą na cel i na dobro. Dzięki woli człowiek skupia się na dążeniu do tego wybranego, jednego celu, który jest jednocześnie celem najważniejszym:

Jest zaś jasne, że wszystkie czynności, które pochodzą od pewnej władzy, są przez nią powodowane stosownie do natury jej przedmiotu. Przedmiotem woli jest zaś cel i dobro. Stąd też wszystkie czynności ludzkie muszą być wykonywane ze względu na pewien cel.

(TS, s. 41)

Święty Tomasz ocenia ludzką działalność (tj. realizację celu) jako naganną bądź godną pochwały wyłącznie na podstawie charakteru samego celu. Dobry cel sprawia, że każde działanie dążące do jego osiągnięcia będzie ocenione jako dobre pod względem etycznym (rodzi się tutaj wątpliwość, czy aby cele nie uświęcają środków). Akwinata zaznacza jednocześnie, że nie do pomyślenia jest możliwość, aby człowiek i jego wolna wola zorientowane były na więcej niż jeden cel ostateczny. Jak sama nazwa wskazuje, cel ostateczny jest tym, do którego wiodą wszelkie działania, a także pozostałe dążenia i cele, znajdujące się niżej w hierarchii ludzkich pragnień. Nie ma już zasadniczo ograniczeń co do liczby owych celów niższych, może ich być dowolnie dużo a każdy z nich jest swoistą drogą kierującą człowieka ku celowi ostatecznemu.

Swoją eudajmonistyczną teleologię wieńczy Tomasz w taki oto sposób: Cel ostateczny to poszukiwane od zawsze i przez każdego szczęście - dobro najbardziej upragnione i najdoskonalsze zarazem. W czym natomiast mieści się owo tak pożądane dobro? Akwinata zdecydowanie odrzuca myśl, że może nim być dowolnie rozumiane bogactwo, zarówno naturalne jak i sztuczne ${ }^{1}$. Wbrew temu, co powszechnie uznaje się za szczęście, nie jest nim cnota, sława czy też władza, choćby i najpotężniejsza.

Szczęście człowieka nie może zawierać się w żadnym dobru stworzonym. Szczęście jest bowiem dobrem doskonałym, które całkowicie zaspokaja pragnienie; inaczej nie byłoby

\footnotetext{
${ }^{1}$ Takie myślenie można odnaleźć w przysłowiach: „Pieniądze szczęścia nie dają", ,"Wielkie pieniądze to wielkie kłopoty", „Pieniądze to nie wszystko".
} 
ono celem ostatecznym, gdyby po jego osiągnięciu pozostawało jeszcze coś do pragnienia. (TS, s. 69)

Ostatecznym celem każdego człowieka, najwyższym, doskonałym szczęściem nie jest dobro indywidualne, doczesne ani bardzo ogólnie pojmowane dobro wszechświata, lecz sam Bóg i radowanie się w Nim. Jak już zostało to wspomniane, osiągnięcie celu jest możliwe dzięki działaniu intelektu i woli. Intelekt dąży do odkrycia prawdy powszechnej, zawartej w najwyższym szczęściu, czego natomiast najbardziej pragnie ludzka wola? Dobra powszechnego, którego nie można odnaleźć w niczym innym, niż tylko w Bogu.

Szczęście najwyższe w ujęciu Akwinaty jest czynnością doskonałą rodzi się więc pytanie: czy w połączeniu z wadliwym ludzkim ciałem dusza (bez skazy) może zyskać doskonałe szczęście? Pamiętając, że tego rodzaju szczęściem jest obcowanie z Bogiem, święty Tomasz dochodzi do wniosku, że w tym przypadku dusza nie potrzebuje ciała - taki rodzaj szczęścia człowiek osiąga dopiero po swojej śmierci.

Szczęście jest doskonałością duszy pod względem intelektu, dzięki któremu dusza wykracza poza narządy cielesne, nie zaś ze względu na to, że jest ona naturalną formą ciała. Dlatego pozostaje w niej doskonałość tej natury, ze względu na którą zasługuje ona na szczęśliwość, chociaż nie pozostaje w niej doskonałość natury, dzięki której jest formą ciała. (TS, s. 95)

Rolą duszy jest obdarzyć ciało ludzkie jak najsilniejszym doznaniem szczęścia: poprzez intensywne radowanie się Bogiem dusza chce tę odczuwaną radość przenieść na ciało. Bez udziału ciała szczęście, owszem, jest osiągane, natomiast połączony udział ciała oraz duszy w szczęściu najwyższym intensyfikuje jego doznania. Należy przy tym mieć na uwadze, że dobro cielesne samo w sobie nie wpływa w żaden sposób na osiągnięcie czy odczuwanie szczęścia najdoskonalszego.

Największa i najważniejsza różnica między szczęściem doskonałym a niedoskonałym (ziemskim) polega na tym, że szczęście niedoskonałe można utracić, co w przypadku szczęścia najwyższego i doskonałego jest niemożliwe. Szczęście osiągnięte w życiu doczesnym człowiek może zdobyć swoimi siłami; szczęście doskonałe człowiek osiąga jedynie dzięki Bożej pomocy, nie świadczy to jednak wcale, że człowiek jest istotą gorszą ponieważ nie może zdobyć szczęścia sam. Człowiek, w odróżnieniu od istot nierozumnych, nie czeka biernie na otrzymanie szczęścia doskonałego; samodzielnie dąży do najwyższego spełnienia i realizacji swoich największych pragnień, zwartych w celu ostatecznym, a Boża pomoc umożliwia mu jego osiągnięcie.

Szczęście najwyższe to dobro, które - jak już wiemy - jest najmocniej pożądane i najsilniej odczuwane przez ludzi. Intensywność doznania tego uczucia może być jednak różna dla poszczególnych osób. Stopień uczestniczenia w szczęśliwości 
zależny jest od skłonności indywidualnych: jeżeli ktoś jest lepiej przygotowany do radowania się Bogiem lub robi to w sposób doskonalszy, staje się szczęśliwszy, niż inni. Pojawia się tu pewna wątpliwość - skoro radowanie się Bogiem jest tym najdoskonalszym celem, do którego podąża każda dusza, dlaczego siła tego doznania jest różna dla poszczególnych dusz? Czy można mówić tu o swoistej dyskryminacji? Czyja dusza bardziej raduje się w Bogu? Ta bardziej zasłużona, należąca do osoby bardziej pobożnej, spełniającej więcej dobrych uczynków niż inne? Jak można w ogóle dzielić dusze na mniej czy bardziej zasłużone do bycia szczęśliwym? Święty Tomasz wyraźnie twierdzi, że stopień uczestnictwa w szczęściu najwyższym zależy od indywidualnych predyspozycji, tak samo jak stopień uczestnictwa w wierze.

Gdy jednak chodzi o osiagnięcie tego dobra czy też radowanie się nim, jeden człowiek może być szczęśliwszy niż inny, ponieważ jest tym szczęśliwszy, im bardziej się nim raduje. Zdarza się zaś, że jeden człowiek raduje się Bogiem w doskonalszy sposób niż inny, ponieważ jest lepiej usposobiony lub przygotowany do radowania się nim. I w ten sposób jeden człowiek może być szczęśliwszy niż inny. (TS, s. 104-105)

Pewne osoby doświadczają wiary intensywniej od pozostałych, przeżywając prawidła i przykazania boskie całą swoją istotą. Tacy właśnie ludzie są predysponowani do bardziej intensywnego radowania się w Bogu po śmierci, nie odbierając ani nie ograniczając pozostałym doznawania szczęścia najwyższego.

\section{5. Święty Tomasz i Wielki Gatsby}

Dlaczego jednak Akwinata w ogóle wspomina o różnicy w odczuwaniu najwyższego szczęścia? Może wpływa na to rozróżnienie poczucie własnej wartości, a może zdolność odczuwania jak różne może być natężenie wiary: skoro istnieją osoby bardziej podatne na wiarę i predysponowane do niej (przyjmijmy, że wybierają one stan kapłański lub zakonny) to istnieją również osoby głębiej doznające radości i generalnie głębiej przeżywające obcowanie z Bogiem. Są to szczególne, niepospolite i wyjątkowe zdolności. Tomasz wyraźnie podkreśla, że po śmierci każdy człowiek osiągnie wprawdzie szczęście idealne, jednak tylko nieliczne grono wybrańców w nagrodę za swoją silniejszą i bardziej żarliwą pobożność zazna go wyjątkowo wiele. Każdego czeka oczekiwane szczęście, każdy będzie radował się w Bogu - to dla Akwinaty kwestie nie budzące wątpliwości. Jego argumentacja w przedmiocie tego, że niektórym osobom (a raczej niektórym duszom) dane będzie odczuwać tę radość mocniej, nie jest zbyt przekonująca o tyle, że Tomasz próbuje waloryzować i racjonalizować wybór życia zakonnego, które, będąc pod pewnymi względami trudniejsze od życia $\mathrm{w}$ stanie świeckim, powinno się traktować $\mathrm{z}$ 
większym szacunkiem ${ }^{2}$. Natomiast osoby świeckie o równie żarliwych przeżyciach religijnych miałyby takiego szczególnego wymiaru szczęścia nie dostąpić.

Idzie o naturalną wątpliwość, która w pewnym momencie opada każdego z nas: czy człowiek, który według swoich kryteriów osiągnął niedoskonałe szczęście ziemskie (dopuszczalne w koncepcji Akwinaty) może czuć się szczęśliwy naprawdę, czy może mieć taką pewność? Niekoniecznie. Ekranizacja (wkrótce ponowna) powieści Francisa S. Fitzgeralda Wielki Gatsby wyraźnie pokazuje, że dążenie do określonych celów, w założeniu ich dawcy mających niezawodnie przynieść szczęście, może zakończyć się wielkim rozczarowaniem. Tytułowy Gatsby zdobył olbrzymi majątek i pozycję, udało mu się ponownie zainteresować sobą ukochaną kobietę. Jednak nie jest on szczęśliwy: każde jego działanie wydaje się być nacechowane wewnętrznym fałszem, nieszczerościa, niespójnościa, a on sam jawi się jako osoba, która w gruncie rzeczy nie wie, czego chce. Teoretycznie osiągnął to, co zamierzał: ma majątek, sławę i (przynajmniej pozornie) prestiż i szacunek, jego dawna narzeczona spotyka się z nim. W rzeczy samej Gatsby nie potrafi cieszyć się z osiągniętych celów.

Nie tylko w literaturze szczęście ziemskie jest tak naprawdę złudzeniem. Przykłady z życia codziennego doskonale pokazuja, że osoby sławne czy bogate wpadają w przeróżnego rodzaju uzależnienia, ponieważ nie czują się szczęśliwe. Nawet ludzie „bliżej Boga” nie potrafią osiągnąć tego, niedoskonałego przecież, szczęścia ziemskiego - przeróżne dzienniki czy wspomnienia osób duchownych ukazuja, jakie przeżywały rozterki i pewnego rodzaju załamania, nie umiejąc czuć radości ze swoich działań. Czy sam święty Tomasz zyskał ziemskie szczęście? Wiadome jest, że oddawał się cielesnym przyjemnościom (obżarstwu), a jego tusza stała się już legendarna. Czy to była jego namiastka szczęścia, czy wręcz przeciwnie - pocieszanie się? Czy to właśnie dlatego Akwinata uznał, że po śmierci część dusz zyska większe radowanie się w Bogu - w nagrodę za określony sposób życia?

Święty Tomasz stworzył swój system etyczny wzorując się na filozofii Arystotelesa. Główną dominantą teleologiczną wszelkich ludzkich działań uczynił szczęście, utożsamiając je z najwyższym dobrem. Powiązanie wartości swoiście chrześcijańskich z ideą antycznej eudajmonii sprawiło, że Traktat o szczęściu wyróżnia się na tle innych średniowiecznych tekstów z zakresu etyki, że przerasta je swoim uniwersalnym spojrzeniem na ludzką kondycję i jej dolę, tę immanentną i tę transcendentną. Trudno sobie wyobrazić filozofię chrześcijańską bez odwołań do

\footnotetext{
${ }^{2}$ Można zastanowić się, czy hierarchizacja osób zbawionych jest zgodna z duchem chrześcijaństwa wedle którego każdy człowiek bez wyjątku zasługuje na zbawienie (traktowane jako jednakowe dla wszystkich).
} 
Boga. System etyczny świętego Tomasza wypływa i kulminuje w Bogu: zakłada bowiem, że to Bóg jest celem głównym każdego człowieka. Jednocześnie podkreśla na każdym kroku, jak istotne jest działanie samego człowieka, mające dopomóc mu w realizacji celów i zamierzeń, jak istotne jest używanie rozumu i woli (na wskroś arystotelesowski motyw u Tomasza) aby układać cele w hierarchię, a na jej szczycie postawić źródło: Boga i szczęście doskonałe. Poznanie Boga, czyli osiągnięcie szczęścia pełnego, doskonałego, wiąże się z przekroczeniem ograniczeń cielesnych i wyzwoleniem duchowym. W życiu doczesnym możliwe jest pozyskanie i doznawanie szczęścia skończonego i niedoskonałego, które jest zaledwie pociechą: aby nie upatrywać w ziemskim żywocie li tylko „padołu łez, krwi i potu” (Augustyn z Hippony) i nie pogrążyć się bez reszty w odmętach rozpaczy, tęsknoty do tego, co boskie i pojednania z nim jako szczęścia ostatecznego (jak uznawał przywoływany na początku Kohelet).

\section{Morał}

Akwinata założył, że szczęście w swojej warstwie doznaniowo-przeżyciowej możliwe jest w każdym momencie ludzkiej aktywności życiowej, aczkolwiek nie należy zapominać o tym, że prawdziwe i pełne szczęście czeka nas dopiero w życiu przyszłym. Wedle Tomaszowych koncepcji obydwa rodzaje szczęścia osiagamy najlepiej, realizując pewne działania (cele), jednak tylko szczęście doskonałe zapewni człowiekowi pełnię radości i spokoju. Może to jest przyczyna, dla której ludzie nie umieją cieszyć się w pełni szczęściem doczesnym, okazują wieczne niezadowolenie ze swej kondycji tutaj, na ziemi, ponieważ odziedziczyli po swych średniowiecznych przodkach tęsknotę, zew przywołujący ku transcendencji? Moim zdaniem odpowiedź Akwinaty na pytanie, czym jest szczęście, jest adresowana do tych, którzy dążą do największego możliwego szczęścia tu i teraz - a ideałem jest ono z racji swej intensywności i pełni, a nie z racji nieskończonego dystansu, jaki ma nas od niego dzielić. Żadna filozofia, teologia ani religia nie mówi nic o tym, że musimy wieść żywot żałosny i zgorzkniały w oczekiwaniu na śmierć, która nas wyzwoli - bo ułatwi duchowy dostęp do Boga i nadzwyczajną, nieznaną nam jeszcze radość z tego stanu rzeczy. Tomasz uświadamia, że szczęście nie jest wykroczeniem przeciwko wymogom wiary. Jeśli zaś szczęście ziemskie to dopiero przedsmak szczęścia niebiańskiego, wypada je pielęgnować tym pilniej.

\section{Literatura}

TS: Tomasz z Akwinu (2008). Traktat o szczęściu, tłum. W. Galewicz, Kęty: Wydawnictwo Antyk. 


\title{
Święty Tomasz, Wielki Gatsby i poszukiwanie szczęścia
}

\begin{abstract}
Abstrakt. Czym jest szczęście? Czy możliwe jest jego osiągnięcie? Czy istnieje jedna definicja szczęścia? Szczęście jako doznanie jest czymś indywidualnym dla każdego człowieka. Filozofia niemal od samego początku swojego istnienia starała się znaleźc odpowiedź na to, czym jest szczęście i jak można je znaleźć. Również Doktor Kościoła, Tomasz z Akwinu, zajął się tym zagadnieniem. Poprzez połączenie myśli chrześcijańskiej z poglądami Arystotelesa św. Tomasz stworzył koncepcję aktualną do dziś.
\end{abstract}

Słowa klucze. Szczęście, najwyższe dobro, dusza, radowanie się w Bogu, teleologia, dążenie do celu.

Autorka. Anna Białas jest magistrem filozofii i filologii polskiej, doktorantką w Instytucie Filozofii Uniwersytetu im. Adama Mickiewicza w Poznaniu. Jej zainteresowania badawcze obejmują filozofię średniowieczną, teologię i etykę.

Dane kontaktowe. Z autorką skontaktować można się pod adresem: anna.bialas@ya.ru.

Cytowanie. Białas, A. (2011). Święty Tomasz, Wielki Gatsby i poszukiwanie szczęścia. Ethics in Progress Quarterly, Volume 2, Issue 2, pp. 123-131, tekst dostępny online na ethicsinprogress.org. 